\title{
LA COMPLEJA CONFIGURACIÓN DE UN DERECHO-LIBERTAD POLIÉDRICO, EL DERECHO A LA INFORMACIÓN. REFERENCIAS HISTÓRICAS
}

LORETO CORREDOIRA Y ALFONSO

REMEDIO SÁNCHEZ FERRIZ 
SUMARIO

I. PLANTEAMIENTO. II. DIFICULTAD METODOLÓGICA DE LA CONSIDERACIÓN HISTÓRICA DE LA INFORMACIÓN POR LA DIVERSIDAD DE SUS PARÁMETROS DE OBSERVACIÓN. III. VARIAS CARACTERÍSTICAS O CONSTANTES QUE NI LAS MÁS AVANZADAS TECNOLOGÍAS PUEDEN MODIFICAR. IV. RECONOCIMIENTO DE DERECHOS EN PERSPECTIVA HISTÓRICA. V. DECLARACIONES DE DERECHOS DE FINAL DEL XVIII, EL UMBRAL DEL NUEVO ORDEN POLÍTICO. VI. EL TARDÍO RECONOCIMIENTO DEL DERECHO A LA INFORMACIÓN. VII. DEFINITIVA FORMULACIÓN CONSTITUCIONAL EN LOS AÑOS 70. VIII. A MODO DE RECAPITULACIÓN. EL SIGLO XXI: LA SOCIEDAD DE LA INFORMACIÓN. IX. BIBLIOGRAFÍA. 


\title{
LA COMPLEJA CONFIGURACIÓN DE UN DERECHO-LIBERTAD POLIÉDRICO, EL DERECHO A LA INFORMACIÓN. REFERENCIAS HISTÓRICAS ${ }^{1}$
}

\author{
LORETO CORREDOIRA Y ALFONSO \\ Universidad Complutense, Facultad de Ciencias de la Información * \\ REMEDIO SÁNCHEZ FERRIZ \\ Universitat de València, Facultat de Dret*
}

\section{PLANTEAMIENTO}

Como todos los derechos humanos, y además fundamentales, el derecho a la información es inherente a la dignidad del ser humano. Ahora bien, creemos que

\footnotetext{
${ }^{1}$ El presente estudio se realiza en el marco del Proyecto MINECO de Excelencia «El avance del Gobierno Abierto. Régimen jurídico constitucional de la implantación de políticas de transparencia, acceso a la información, datos abiertos, colaboración y participación especialmente a través de las TIC y del gobierno electrónico» DER2015-65810-P (2016-2018), cuyo IP es Lorenzo Cotino Hueso. Una versión preliminar fue defendida por ambas autoras en la Universidad de Leicester durante el Forum Internacional de Ética y derecho a la información, Comunicar. Derecho o deber en julio de 2016, como preconferencia de la IAMCR, Congreso internacional de la International Association for Media and Communication Research. Dentro de la IAMCR fue asimismo defendido en el panel «Lessons after 40 years of experience teaching Communication Law «, 28th july 2016. https://iamcr2016conference.sched.org/ event/7cuG/lessons-after-40-years-of-teaching-communication-law-at-the-journalism-schools-experiencias-de-40-anos-de-ensenanza-universitaria-del-derecho-de-la-informacion\#

* Loreto Corredoira y Alfonso. Profesora Titular de Universidad. Departamento de Derecho Constitucional. Facultad de Ciencias de la Información. Universidad Complutense. Avda Complutense, s/n, Edificio nuevo, Despacho 123.28040 Madrid (España).Email: loretoc@ucm.es

* Remedio Sánchez Ferriz. Catedrática. Departamento de Derecho Constitucional, Ciencia Política y de la Administración. Facultad de Derecho Universidad de Valencia Campus de los Naranjos, s/n. 46071 Valencia (España). Email: remedio.sanchez@uv.es
} 
la observación de su proceso de configuración histórica nos aporta muchos motivos de consideración sobre sus peculiaridades pues la evolución de este derecho ha discurrido en un modo muy especial que se aparta de otros derechos tan naturales y fundamentales como el que ahora nos ha de ocupar.

Tal vez por ello Desantes Guanter recurría con frecuencia al Derecho natural y muchas veces, aun sin mencionarlo, el iusnaturalismo impregnaba todas sus consideraciones sobre este derecho especial en el que llegó a ser el citado profesor especialista indiscutido en el ámbito hispano-parlante ${ }^{2}$. Visto hoy desde el extraordinario desarrollo legal que la información ha adquirido (hasta el punto, a nuestro juicio, de desfigurarse a veces su propia naturaleza y caracteres en obtusa confusión de conceptos derivada de la sobre inflación legislativa), sin duda aquellas consideraciones de los años 70 pueden parecernos simplistas y, desde luego, son preconstitucionales. Pero ello no resta interés, al contrario, a una reflexión retrospectiva que nos permitirá reconducir los elementos más esenciales de este derecho a su justa posición tanto en el marco de los derechos fundamentales y las libertades públicas como en la particular función que desempeña en la vida social y política, muy especialmente, en la vida democrática.

\section{DIFICULTAD METODOLÓGICA DE LA CONSIDERACIÓN HISTÓRICA DE LA INFORMACIÓN COMO ASPIRACIÓN Y COMO DERECHO}

\section{Por la diversidad de sus parámetros de observación}

Decíamos que el derecho a la información es inherente a la dignidad humana pero ello no impide que tenga muy diversas facetas según se invoque (y se reconozca) en multitud de situaciones de carácter privado o en la manifestación social y política del ser humano. Sus distintas manifestaciones se han invocado (y reconocido) a lo largo de la historia pero la de carácter político (propia de la condición de ciudadano en un régimen democrático) ha sido la más tardía. La información como condición sine qua non de vida social inherente a la condición humana (que no en vano ha ido evolucionando con el lenguaje y sus manifestaciones) presenta una evolución histórica tan sumamente compleja que no podría

${ }^{2}$ José M. ${ }^{a}$ Desantes Guanter (1924-2004), fue el primer Catedrático de Derecho de la Información en la Universidad española. Cfr. Memoria cátedra publicada en el libro Fundamentos del Derecho de la Información, Confederación Española de Cajas de Ahorros, 1977. Su primera obra, prácticamente coetánea a la de la coautora de este trabajo Remedio SÁnCHEz FERRIZ (El Derecho a la Información, Valencia 1974) fue El autocontrol de la actividad informativa (Madrid, 1973). 
comprenderse sin recurrir a diversos referentes del mismo fenómeno jurídico y social. Ello es así en tanto que su desarrollo no solo ha comportado el reconocimiento y la superposición de nuevas facultades o derechos (cabría decir en este sentido que el derecho a la información es un derecho poliédrico o, en sentido histórico, de aluvión), sino también la modificación de la naturaleza y características de cada una de sus manifestaciones que, sin desaparecer, han ido quedado atrás, o dejando de ser el foco de atención, a medida que el desarrollo tecnológico ha desplegado sus efectos sobre este concreto objeto del Derecho que ahora nos ocupa. Precisamente la configuración que hoy observamos del derecho a la información tras años de crecimiento de las tecnologías relacionadas con Internet (web semántica, redes sociales, almacenamiento en nube, movilidad, internet de las cosas, etc.) sigue planteando a los académicos retos de análisis y clarificación terminológica, lo que también se requiere en instancias judiciales.

El derecho es poliédrico en su origen como explicaremos y también en su contenido porque abarca facultades tan antiguas como la de «acartelar» (droit d'afficher) hoy ejercida en la publicidad o por los grafiteros que adornan los muros de vías del tren y ciudades; el derecho de manifestación, también con connotaciones políticas y democráticas; la facultad o actitud participativa de usuarios de sitios sociales que bloguean, tuitean o..., en definitiva, publican y difunden: de la publicidad directa hemos pasado a la difusión mediante mensajería instantánea; hoy son los «whatsapps», lo que en los 90 los correos electrónicos». Difundir, recibir o investigar son las tres facultades que se alumbraban en las declaraciones de libertades del siglo XviII. Hoy el derecho a imprimir o el derecho de antena se ha complementado — sin ser distinto en su esencia- con otras de sus facultades. Recientemente la de investigar ha conocido una gran expansión en su ejercicio, no solo en el ámbito público — mediante las primeras acciones de trasparencia o acceso a documentos oficiales — sino también en lo privado.

\section{Por las múltiples caras de este derecho-libertad}

A grandes rasgos podríamos representar una sucesión de facultades (que derivan unas de otras ${ }^{3}$ ), sin que respondan solamente a un orden estrictamente

3 Libertad de conciencia (inicialmente vinculada a la religiosa) — Libertad de pensamiento — Libertad de expresarse — Libertad de hacerlo a través de la imprenta y, en especial, a través de la Prensa y, progresivamente también a través del Libro, de la Radio, de la Televisión, del Video, del Teatro y Cine y, naturalmente navegando en Internet o comunicando a través de las Redes sociales. Pero, hasta aquí, no parece discutible que nos hallamos en el ámbito amplísimo de la Libertad de Expresión (Fig. 1). 
cronológico, y que representamos (no sin precisar que ni su naturaleza ni su contenido cambian a lo largo de tan dilatado proceso, solo cambia el medio o soporte auxiliar).en las siguientes imágenes:

Fig. 1. Sucesión de facultades de la libertad de expresión

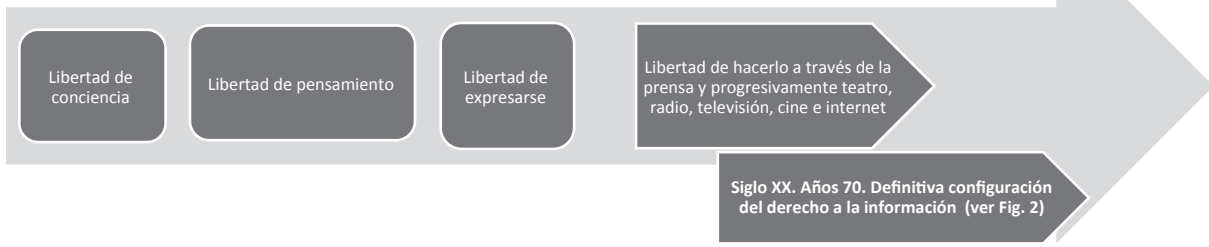

Por su parte el Derecho a la Información (Fig. 2) asoma a su formulación, y acaba conformándose en toda su extensión pero en el ámbito doctrinal; mientras que su consagración constitucional (a diferencia de la libertad de expresión que procede del primer constitucionalismo) se produce tardía y lentamente a partir de la segunda postguerra y, además, aparece en las grandes declaraciones contemporáneas (de 1948 y 1950) solo como una facultad de la vieja libertad de expresión ${ }^{4}$.

Fig. 2. Configuración del derecho a la información

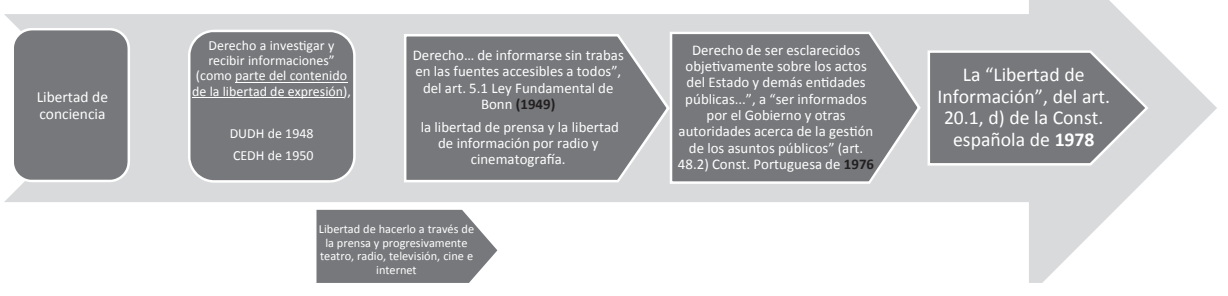

Así, cabe observar la progresión en la construcción conceptual del derecho a la información en la siguiente enumeración en la que observaremos más aproxi-

4 Dando así apoyo a la llamada doctrina monista en cuya virtud el derecho a la información derivaría de la libertad de expresión, siendo una de sus manifestaciones. 
maciones que definitivas formulaciones pese a lo avanzado del período a partir de la II Guerra Mundial:

- El «Derecho a investigar y recibir informaciones» (como parte del contenido de la libertad de expresión), según la DUDH de 1948 y el CEDH de 1950 $\mathrm{y}$, en forma semejante, la «Libertad de buscar, recibir y difundir informaciones e ideas de toda índole», del PDCP de la Asamblea de Naciones Unidas de 1966.

- El «Derecho... de informarse sin trabas en las fuentes accesibles a todos», del artículo 5.1 Ley Fundamental de Bonn (1949) en cuyo texto la garantía de las dos libertades se enuncia por separado: la libertad de prensa y la libertad de información por radio y cinematografía.

— El «Derecho a informar, a informarse y a ser informados», del artículo 37 de la Constitución Portuguesa de 1976 que distingue la libertad de expresión y la de información.

— El «Derecho de ser esclarecidos objetivamente sobre los actos del Estado y demás entidades públicas...», a «ser informados por el Gobierno y otras autoridades acerca de la gestión de los asuntos públicos» (art. 48.2 de la misma Constitución Portuguesa que proclama tal derecho como fundamento de la participación política).

— La «Libertad de Información», del artículo 20.1, d) de la Constitución española de 1978 que, por interpretación del Tribunal Constitucional (TC) se ha configurado como libertad distinta a la de expresión del mismo artículo y párrafo, reconocida en la letra a) y, por consiguiente, conformando dos derechoslibertades distintos.

\section{Además, por el efecto directo de las tecnologías}

Por continuar con ejemplos simples y evidentes, baste recordar ahora el efecto de la invención de la imprenta en el siglo xv, o el desarrollo de la radio y la televisión en el siglo xx, o de la expansión del uso de internet en el presente. La reciente reflexión de Abad sobre el derecho a la información en el ámbito europeo $^{5}$ constituye un buen ejemplo, entre tantos, de la inseguridad o ambigüedad conceptual con que los más Altos Tribunales de la Europa democrática resuelven los conflictos cada vez más complejos que los adelantos tecnológicos

5 Abad Alcalá, L. (2015), «El derecho a la información y las libertades informativas en el ámbito europeo», en Bel Mallén, I. y Corredoira y Alfonso, L. (dirs.) (2015), Derecho de la información. El ejercicio del derecho a la información y su jurisprudencia, Madrid, CEPC, pp. 69-95.

(C) UNED. Revista de Derecho Politico 
plantean ${ }^{6}$. También Cotino y Corredoira ${ }^{7}$ han abundado en la dificultad conceptual para la defensa de los derechos personales ante las Tecnologías de la Información y Comunicación (TICs): «en las TICs los interrogantes se abren con mucha más rapidez y profundidad que las respuestas que el Derecho brinda al fenómeno de Internet. Los juristas no hemos resuelto las dificultades (de) ...la web 1.0... Tan siquiera hemos vislumbrado todos los problemas que surgen en la web 2.0, que ya no es tan novedosa. Mientras tanto, y como una ola gigante de la «Tormenta perfecta», se vienen encima de las cuestiones planteadas la web 3.0 o internet de las cosas, los problemas que suscita la nube, el «big data» y la gestión ingente de datos con su tratamiento automatizado y profundo, inaccesible conocimiento para los usuarios...».

Por ello, hoy más que nunca se deberían recordar los elementos esenciales de la información como derecho que, sin perjuicio de su transmisión a través de tan novedosos medios como ofrece la tecnología, deben seguir constituyendo referentes de aplicación a cada conflicto que la propia información puede generar. Pues si la aparición de nuevas tecnologías ha dado lugar a nuevas (y sucesivas) formas de manifestación del pensamiento ideas y opiniones, pero siempre conformando (y nutriendo) la misma libertad de expresión, en el caso del derecho a la información las últimas tecnologías, fundamentalmente el uso de las redes sociales, comportan cambios en su concepción que nos obligan a hacer un esfuerzo de deslinde o precisión conceptual. Piénsese que la libertad de expresión es patrimonio de todo ser humano (no solo en el sentido de su titularidad, sino también de los contenidos con que la dotemos en cada caso) y, por consiguiente, cualquiera que sea el medio por el que se ejerza, no va a cambiar su función que se halla vinculada al emisor o sujeto único. Pero en el caso del derecho a la información, junto a sus titulares-destinatarios, hay unos sujetos obligados a facili-

6 Aunque a nuestro juicio cabría una mayor claridad de posiciones si se partiera de un concepto claro de lo que conforma las libertades informativas; si bien las tecnologías y las eventuales situaciones de conflicto sí pueden variar ostensiblemente, los puntos de partida conceptuales deberían hallarse más consolidados y creo que no es así. Es cierto que la técnica avanza extraordinariamente y en consecuencia la imposibilidad de fijar fronteras pero igual que existen pautas comunes que nos permiten reconocer lo que exactamente sean intereses de orden económico que defienden las empresas o las personas e intereses humanos vinculados a la intimidad y/o personalidad de cada cual, debe tenerse por aceptado un ámbito protegido para las libertades informativas que bien podría estar vinculado al interés público o general, pues no es la invocación de la información lo que la legitima sino el uso legítimo de la misma lo que fortalece su protección ( $C f r$. SÁnchez Ferriz, R., Delimitación de las libertades informativas, Valencia, Tirant Lo Blanch, passim).

7 Corredoira y Alfonso, L. y Cotino Hueso, L. (eds.) (2013), Libertad de expresión e información en Internet. Amenazas y protección de los derechos personales, Madrid, Centro de Estudios Políticos y Constitucionales. 
tarla y los intermediarios (en formas y soportes diversos y con tratamiento jurídico también diverso) y existe, sobre todo, un contenido constitucionalmente delimitado (e incluso ontológicamente, vinculado a la misma idea de información ${ }^{8}$ ) que sí puede verse afectado por las «novísimas» tecnologías.

\section{VARIAS CARACTERÍSTICAS O CONSTANTES QUE NI LAS MÁS AVANZADAS TECNOLOGÍAS PUEDEN MODIFICAR}

\section{La comunicación interpersonal como condición de humanidad y de la constitución de toda comunidad ${ }^{9}$}

Cualquiera que sea su ámbito y naturaleza toda convivencia presupone la comunicación desde las primeras manifestaciones sociales humanas hasta la presente sociedad tecnologizada (no en vano conocida como «de la Información» entendida esta, como precisa Yolanda Gómez, en su más amplio sentido ${ }^{10}$ ); cuestión distinta es si dicha comunicación se lleva a cabo en términos de igualdad entre los miembros de la comunidad o de supra e infra posición. Y ello ya nos permite sentar la primera de las afirmaciones de las que queremos partir como no puede ser de otro modo para quienes reflexionamos desde el Derecho Constitucional:

A) La comunicación, como la información, cuando más allá de lo filosófico traspasan el mundo de lo jurídico, son fenómenos íntimamente unidos al del poder. Así se comprende que puedan ser muy diferentes las ideas de comunicación en tribus primitivas o incluso en las familias sin estructura respecto la familia clásica romana en la que el pater familias llega a disponer de la vida de sus miembros (figura que, no en vano inspiraría a Bodino en la búsqueda de la conformación de una comunidad política con poder soberano). En última instancia, el tratamiento de la información depende de la conformación política concreta. Ello permite entender perfectamente las respuestas históricas del Dere-

8 Prólogo de Desanter Guanter, J. M. a a la obra Derecho de la información, Ignacio Bel Mallén y Loreto Corredoira y Alfonso (coords.) (2003), Barcelona, Ariel.

9 Más aún, precisa Joan Robinson que ni la sociabilidad ni la capacidad de comunicación constituyen la característica específica del individuo, «la característica distintiva de la humanidad es la invención de un lenguaje que transmite información de cosas que no están presentes y permite especular sobre cosas no conocidas. Los monos superiores tienen modales, es el lenguaje el que hace hombre al hombre».

10 Gómez SÁnchez, Y., «La Sociedad de la Información en Europa», en Torres DeL Moral, A., dir. (2009), Libertades informativas, COLEX, Madrid, p. 1220. 
cho ante el fenómeno, pero también explica las reacciones negativas del poder no democrático frente a toda difusión de ideas que la información comporta. No en vano, será imposible hablar de derechos reconocidos hasta las primeras declaraciones de derechos modernas. Y, para la información aún habrá de esperar siglo y medio más para que pase a constitucionalizarse el flujo informativo como un derecho fundamental. De hecho, desde esta perspectiva de la relación de los derechos con el poder, y refiriéndose a la época constitucional, Sánchez Ferriz ${ }^{11}$ ha sostenido en varias ocasiones una interpretación de las generaciones de derechos divergente de la mayoritaria (compartida, entre tantos por Pérez Luño en España y Barile en la doctrina italiana) en cuya virtud se entiende que existen tres generaciones de derechos incluyendo a las libertades públicas en la primera de ellas. Por el contrario, la posición minoritaria a que se alude entiende que las libertades públicas, como grupo especial de derechos entre las que ocupan una posición nuclear las libertades informativas, constituyen una generación distinta de la de los derechos individuales que ya se constitucionalizan en el primer constitucionalismo debiendo esperar las libertades públicas (para ser constitucionalizadas) al posterior proceso de democratización del Estado Liberal y a los efectos sociales y políticos derivados del movimiento obrero y de la transformación de los Parlamentos a través de la consolidación de los fenómenos de masas y su reflejo en los nuevos partidos de masas $^{12}$.

B) La segunda característica de la evolución es, en efecto, su vinculación a cierto grado de desarrollo social y político. Las libertades públicas son derechos que solo se practican con garantías en sociedades desarrolladas y muy en particular lo es la matriz de todas ellas, la libertad de expresión en todas sus manifestaciones ${ }^{13}$. Quiere decirse que solo habrá garantía para las libertades informativas donde haya régimen democrático o, dicho de otro modo y con mayor precisión, las libertades informativas (como en general todas las libertades públicas), son parámetro de democraticidad ${ }^{14}$. Por ello, no cabe hablar en rigor de derecho a la información donde no se hayan desarrollado y practiquen las libertades públicas

11 SÁnChez Ferriz, R. (1995), Estudio sobre las libertades. Valencia, Tirant Lo Blanch.

12 Los ejemplos de ese paso de un marco político a otro (generalmente ignorado por la posición mayoritaria sobre las generaciones) podrían multiplicarse pero considero muy gráfica la intuición con que Tocqueville advierte el cambio social que se avecina al escuchar en un mitin de próceres, por vez primera, a un obrero: «Rara vez en mi vida me he visto subyugado por la palabra como lo fui aquella tarde oyendo hablar a ese hombre del pueblo... veía en él al precursor de esos revolucionarios que un día, sin duda, tratarán de cambiar la faz de Inglaterra. La vieja y la nueva sociedad inglesa parecían estar aquí presentes y querer luchar cuerpo a cuerpo...» (TocQUEVILLE, A. (1978). Igualdad social y libertad política, Madrid, Aldaba, pp. 47-48.

13 Por todos Braud, Ph. (1968), La Notion de Liberté Publique en Droit Français, Paris, 1968.

14 SÁNCHEZ FERriz, R. (1995), Estudio sobre las libertades..., op. cit. 
de las que nuestro derecho constituye su fundamento y síntesis como refiere Carlos Soria: «...es, por decirlo de alguna manera, el derecho-síntesis de los derechos de contextura social. Sobre esa base, el derecho a la información es a su vez catalizador y fermento del conjunto de los derechos políticos y sociales en el sentido de... hacer posible la comunidad...» ${ }^{15}$.

Y debemos también precisar que antes de que adquiera relevancia política y constitucional la información se reconoció progresivamente en sus facetas privadas a las que el derecho dio cobertura, no siendo por tanto este derecho una excepción en la regla general que permite afirmar que el Derecho público se ha ido nutriendo a lo largo de la historia de las categorías que ya desde Roma fue conformando el derecho privado. Ello no obstante la peculiaridad del derecho a la información desde la perspectiva del derecho Constitucional reside en la función esencial que el mismo cumple en todo sistema democrático hasta el punto que, como afirma Jorge de Esteban ${ }^{16}$, «los medios de comunicación y, en especial, la prensa diaria, radio y televisión aparecen teóricamente, en nuestras sociedades democráticas modernas, como el último reducto de libertad de los ciudadanos y, por tanto, como un instrumento decisivo para controlar el poder político». De ahí que no quepa confundir los derechos individuales con los que tienen un claro componente social como son las libertades públicas y, en especial, esta faceta pública del derecho a la información que aquí se quiere subrayar.

C) Todo lo cual no empece para que antes de su constitucionalización haya habido una percepción doctrinal relevante en concretos autores a que nos referiremos y que la previa formulación filosófica y doctrinal de las mismas pueda remontarse al pensamiento clásico (Sófocles, Eurípides, Marco Aurelio, Ulpiano entre otros) del que bastará con citar algún ejemplo. Así, no podemos olvidar el reproche que Hemon, hijo del rey Creonte, dirige a este en defensa de Antígona poniendo de relieve el sentir del pueblo; ante la obcecación del rey que desoye tal sentir popular y se obceca en sus propias decisiones, el hijo le espeta: «tú has nacido, padre, para gobernar tú solo una ciudad de muertos ${ }^{17}$... En Las Suplicantes Eurípides contrapone las virtudes de la democracia (en boca de Teseo) y la tiranía que Tebas representa (en boca del heraldo) afirmando aquél: «Esta ciudad no la manda un solo hombre, es libre. El pueblo es soberano mediante

15 Soria Saiz, C. (1987), Derecho de la información. Análisis de su concepto. San José de Costa Rica, ECAM, p. 66.

16 De Esteban, J. (1996), «Medios de comunicación y Estado de Derecho», p. 466, en Asensi SABAter, J. (coord.), Ciudadanos e instituciones en el constitucionalismo actual, Valencia, Tirant lo Blanc, pp. 465-488.

17 Sófocles (422 a. C.), Antígona, en http://agonzalez.web.wesleyan.edu/span253/texts/ sofocles_antigona.pdf 
magistraturas anuales alternas y no concede el poder a la riqueza, sino que también el pobre tiene igualdad de derechos...» ${ }^{18}$. No menos expresivas son las consideraciones de Marco Aurelio: «Mientras que los demás seres son mantenidos en unión por diversas fuerzas, la Inteligencia (dianoia), por un privilegio singular, tiende a establecer vínculos entre los hombres y a satisfacer así la necesidad de comunicación, más allá de todos los obstáculos...» (Soliloquios, X, 30).

D) Ello es una constante histórica. No es de extrañar, pues, que antes que la libertad de expresión primero, y el derecho a la información después, alcancen su reconocimiento constitucional, podamos hallar multitud de manifestaciones de orden filosófico y/o político que recorren toda la historia de nuestra civilización ${ }^{19}$. En efecto, toda reflexión que pueda considerarse precedente del pensamiento liberal en el que el individuo será considerado digno de ser tenido en cuenta a la hora de organizar la vida social, hallaremos explícita o implícitamente contenida la idea de la información; y en algunos casos en que el pensamiento ha madurado también encontramos la información en un importante aspecto que fue destacado por Desantes, como deber de dar a cada uno lo suyo ${ }^{20}$ por cuanto forma parte de la idea de justicia hasta el punto que Santo Tomás identificaba una y otra: Iustitia consistit in communicatione. Si justicia en la definición de Ulpiano es dar a cada uno lo suyo, el deber de informar consiste en dar a cada uno la información que le corresponde como propia. Retoma esa idea clave Desantes ${ }^{21}$ cuando afirma que «el acto informativo es, fundamentalmente, un acto de justicia».

Y ello nos permite recordar aspectos que, como ya se ha aludido, hoy parecen quedar olvidados ante el peso extraordinario que la información ha adquirido en los sistemas democráticos. Se tiene a veces la impresión que hoy se protege el mayor flujo posible de información (o de lo que aparentemente es información) sin entrar a valorar su naturaleza, su lógica o sus fines. Y por supuesto no puede ni debe hacerse valoración alguna con carácter previo, pero sí se echa de menos en las sentencias de tribunales nacionales e internacionales cierta claridad con-

18 Euripides (423 a. C.), Las Suplicantes, disponible en la URL http://ebiblioteca.org/?/ ver/64422

19 Para un completo repaso de significativos referentes históricos Torres, A. y NAVAs, F. «Encuadramiento terminológico y evolución histórica de las libertades informativas», en TorRES DEL Moral, A. (2009), Libertades..., ya cit., pp. 15-69; en especial para lo apuntado en texto, pp. 19-45.

20 Desantes Guanter, J. M.' (1976), La función de informar, Pamplona, Universidad de Navarra, p. 161.

21 Desantes Guanter, J. M. a et al. (1994), Derecho de la Información, vol. 2. Los mensajes informativos, Madrid, Colex, p. 14. 
ceptual que aporte reglas de actuación a un sujeto potencialmente activo que hoy (a través de las tecnologías) es tan dilatado como el pasivo. Claro que el derecho a la información es axial, es presupuesto insoslayable de toda democracia. Pero también lo es del progreso jurídico tal como aquí se está razonando pues también la información ha ido acompañando tal progreso en todas sus manifestaciones por más que fueran de naturaleza privada ${ }^{22}$. Así, pues, su extraordinaria democraticidad no basta para un uso que desconozca otros elementos no menos importantes del ordenamiento jurídico.

\section{Progresión histórica de la construcción del derecho estudiado}

Centrándonos ahora en las consideraciones históricas de naturaleza jurídico política, haremos alguna referencia a las «libertades-privilegio» medievales, a las primeras declaraciones liberales de derechos y a la posterior formalización o constitucionalización de las libertades informativas. Esta es la secuencia de hechos (Fig. 3) que — de acuerdo con lo ya indicado anteriormente en Fig. 1seguimos completando.

Fig. 3 Consideraciones históricas de naturaleza jurídico-político

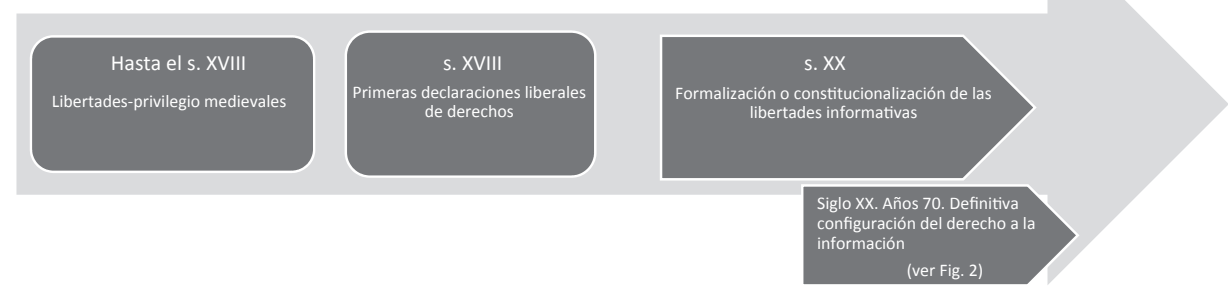

\section{RECONOCIMIENTO DE DERECHOS EN PERSPECTIVA HISTORICA}

¿Hay derechos en el medioevo? Los hay, pero no cabe confundirlos con los que hoy conocemos, pues «la conciencia clara y universal de los derechos es pro-

${ }^{22}$ Un ejemplo con el que ilustrar la idea sería el derecho de toda persona adoptada a conocer sus orígenes biológicos. 
pia de los tiempos modernos» ${ }^{23}$ y ello, siendo así, no ha podido llegar a cuajar hasta que la relación del poder soberano pueda ejercerse directamente sobre todos los súbditos sin interposición de tantos poderes, jurisdicciones e inmunidades presentes en el mundo medieval que impiden la configuración de un ordenamiento jurídico general. Tal es el logro del constitucionalismo desde la perspectiva jurídica puesto que la conciencia ética, aunque no totalmente extendida, sí cuajó antes en un orden ético natural que inicia el estoicismo y secunda el cristianismo para desarrollarse por la teología española de los siglos XVI y XVII (Vitoria, Las Casas, Suárez, etc.), que no en vano representan precedentes ideológicos de la posterior manifestación liberal ${ }^{24}$. Solo que el salto al ámbito jurídico y político no solo requerirá de las formulaciones liberales; también, de las técnicas racionalizadoras (de las que la división de poderes constituye el paradigma). Pues bien, las Declaraciones de fines del XVIII son, también, técnicas imbuidas de la importancia de la escritura y la solemnidad de los documentos propios del racionalismo que las inspira; pero ellas solo se alcanzan a partir de las revoluciones burguesas cuando las ideas hayan ido cuajando lentamente hasta hallar las condiciones que con tales revoluciones eclosionan.

\section{Derechos y/o libertades "privilegio», propios de la sociedad feudal}

El interés del movimiento constitucional de fines del XvIII, fruto de las revoluciones burguesas, justamente se pone de relieve por contraposición con los documentos medievales en que se reconocen derechos, libertades e inmunidades. Dicha comparación permite advertir lo que realmente es propio de cada uno de tales sistemas y su significación en el marco histórico en que se desarrollan. Los documentos medievales son múltiples y merecen destacarse entre ellos los ingle$\operatorname{ses}^{25}$ sin que, desde luego, tampoco quepa ignorar la importancia de los documentos españoles ${ }^{26}$. Son en conjunto muchos más que las modernas Declaraciones que abren la historia contemporánea lo que resulta lógico si observamos las

23 Truyol y Serra, A. (2015), Estudio preliminar a Los derechos humanos, Madrid, Tecnos, p. 12 .

24 Fernández de Marcos Morales, R. J. (2009), «A propósito de algunas re-lecciones de Francisco de Vitoria», Revista de Derecho UNED, núm. 4.

25 Entre los documentos medievales, suelen citarse como más destacados los documentos ingleses: a) Writ of Habeas Corpus (de origen inmemorial), b) Charta Magna Libertatum (1215), c) Petition of Rights (1628) y Bill of Rights (1689), las dos últimas fuera del periodo medieval pero respondiendo al mismo planteamiento que aquí queremos subrayar.

26 En efecto, no menos significativos son nuestros documentos e instituciones conocidas como Cartas de población, Fueros locales y generales, Leyes dadas en Cortes o Juramentos de Prínci- 
diferencias entre unos y otros que son bien notables: 1. Aquellos, los medievales, se dan a grupos sociales concretos y estas, las declaraciones modernas, se proclaman para todos los hombres, 2. Aquellos tratan de resolver concretas situaciones de conflicto entre el Rey y los nobles, o de relaciones entre el Rey y concretas ciudades en las que este suele hallar apoyo, mientras que las Declaraciones modernas se formulan con pretensión de universalidad, partiendo de una nueva concepción del ser humano.

Estas simples referencias nos permiten advertir la aparente existencia ya en la Edad Media de derechos y libertades. Pero la cuestión no es solo si existieron o no derechos, sino la de determinar su significación política, su método de adopción y su significado cara a la pervivencia en un prolongado futuro que llega hasta hoy. Pues, de una parte, en estos documentos de impronta medieval es cierto que se otorgan derechos a grupos y/o territorios que van generando una nueva mentalidad y arraigándose como tradición, pero, de otra, no son sino un signo más de profundas desigualdades entre grupos humanos, no solo naturales sino, también, jurídicas. El ejemplo de la primera y más conocida de las declaraciones medievales citadas puede ser clarificador para responder a la cuestión propuesta: La Carta Magna Libertatum, que firma Juan sin Tierra en 1215, es referente del origen de la idea de los derechos que nada sin embargo tienen que ver con los que se redacten a fines del XVIII pero sí nos permiten valorar la especial significación con que las declaraciones dieciochescas se formulan. El incipiente derecho a ser informado del detenido (otra cara más del poliédrico derecho a la información), las libertades civiles básicas de propietarios, herederos, la protección de viudas, son una «regla» jurídica de convivencia que sigue siendo la base del Derecho privado y del público constitucional ${ }^{27}$.

\section{Transversalidad del derecho a la información; imposible configuración de su faceta pública hasta que existan sociedades democráticas}

Siendo ciertas estas afirmaciones de carácter general, aun debemos precisar más en lo que se refiere a la especial configuración del derecho a la información. Su especial significación impedirá que nazca con las declaraciones de fines del siglo XVIII pero, sin embargo, en diversos aspectos sí ha estado presente en las

pes, etc. El Prof. Castán Tobeñas, buscando los antecedentes de lo que en el siglo xx llamaríamos derechos del hombre, citaba un buen número de ellos.

27 Véase Fisher, J. (2015), «Why Magna Carta still matters today», publicado con motivo de los 800 años de su promulgación, disponible en https://www.bl.uk/magna-carta/articles/whymagna-carta-still-matters-today 
formas políticas precedentes y en las instituciones propias de cada una de ellas. Y ello, tanto en el ámbito del Derecho Privado (buenos ejemplos podemos hallar en las propias instituciones privadas del derecho romano y su posterior aplicación en la etapa medieval, incluidas las citadas previsiones de la Carta Magna de Juan Sin Tierra ${ }^{28}$ ) como en el Derecho Público que a partir de entonces se ira forjando; sin duda la configuración de los Parlamentos y su forma de deliberar, cuando logran reunirse, constituyen el precedente paradigmático de lo que habrá de ser la información cuando nazcan las sociedades democráticas. Ni faltan precedentes y reflexiones doctrinales como la que Desantes destacaba como formulación del ius communicationis de Francisco de Vitoria ${ }^{29}$; la especial aportación de Vitoria consiste en romper el particularismo de la Edad Media (también en el campo de los derechos) para concebirlos con la universalidad que solo después en el XVIII hallará el terreno abonado para ser aceptada. En efecto, con tal concepción de igualdad en la titularidad de los derechos, Vitoria se los reconocía igualmente a los españoles y a los indios (con una doble concepción de derecho-deber), entre los que mencionaba la «natural comunicación, la asociación libre, comercio, emigración...». La idea, sin duda, entronca con la concepción de Aristóteles sin aportar mucho más que el recordatorio de la naturalidad con que la comunicación ha de hacer posible la comunidad y viceversa, no siendo posible una sin la otra.

Pero tal derecho, pese al extraordinario interés de las aportaciones doctrinales, solo llega a sus primeras aproximaciones conceptuales (que no propiamente formulación) en varias formas (en especial, la de la invocación de la opinión pública) cuando el siglo de las luces vaya configurando tales «luces» como la esencia de las nuevas sociedades y sus correspondientes gobiernos. Hasta entonces el poder no ha desarrollado sino técnicas de «silencio» o de miedo a la información ${ }^{30}$. Las formas inquisitoriales bien conocidas en la España de los siglos XVI-XIX son el mejor ejemplo, pero no el único; pues es inherente a todo

28 En el establecimiento de bases jurídicas que la misma contiene trasciende la implícita necesidad de información en cuantos preceptos comportan adopción de decisiones de carácter general: así, «...Para obtener el consentimiento general al establecimiento de un «auxilio»... o de una «fonsadera» haremos convocar individualmente y por carta a los arzobispos, obispos, abades, duques y barones principales... A quienes posean tierras directamente de Nos haremos dirigir una convocatoria general... para que se reúnan un día determinado (que se anunciará con cuarenta días, por lo menos, de antelación) y e n un lugar señalado... Se hará constar la causa de la convocatoria en todas las cartas de convocación... ».

29 Desantes Guanter, J. M.' (1999), Francisco de Vitoria, precursor del Derecho de la Información, Fundación de la Comunicación Social, Madrid, p. 41

30 Una síntesis histórica de lo que Terrou llama el régimen preventivo, siempre presente en la prensa desde sus formas más incipientes hasta la regulación propia del constitucionalismo 
poder absoluto el control de la información en todas sus formas; e incluso en la etapa constitucional la invocación de la opinión pública no impide que se tema la expansión de las ideas nuevas incluso a través de la Cátedra ${ }^{31}$. Y no se olvide que la liberalidad de las Cortes de Cádiz al aprobar la primera Ley de imprenta ${ }^{32}$ queda también extraordinariamente limitada en su objeto.

Todo lo cual viene a confirmar una de las características ya mencionadas: libertades informativas y sociedades democráticas constituyen un binomio insoluble cuya interrelación opera en los dos sentidos: ni caben libertades informativas sin compromiso democrático, ni podría perdurar una democracia en la que no se practicara la libertad informativa y el derecho a conocer cuanto incumbe a la comunidad.

\section{La libertad de expresión como primer pilar de la nueva sociedad liberal}

Tal convicción ya se percibe antes que se formalice la libertad de expresión como en forma paradigmática podemos observar en Milton ${ }^{33}$ : la libertad de expresión es la cima de todas las libertades según la presenta Milton ante el Parlamento inglés en 1644 en una defensa que aun hoy se considera el nacimiento de tal libertad. Su aportación, más que en tal defensa, reside en haber concebido la libertad de expresión en todas sus dimensiones y potencialidad social y política ${ }^{34}$; matar un buen libro, dirá, es casi matar un hombre: «Quien a un hombre mata quita la vida a una criatura racional, imagen de Dios; pero quien

democrático de la segunda postguerra, en Terrou, F. (1970). La información. Barcelona, Oikostau, pp. 13 a 84 .

31 García Trobat, P. (2015), «El manual mata la cátedra»; en Romano, Andrea (cur.) (2015). Dalla lectura all'e-learning. Bologna, CLUEB, pp. 227 y ss.) resalta la función de control que desempeñan los manuales (textos muertos) respecto de los «textos vivos» que no dejaban de ser una referencia a las explicaciones de los catedráticos que representaban mayor dificultad de controlar la expansión de las ideas; pp. 236-237.

32 García Trobat, P. (2011), La libertad de imprenta, aliada de la revolución, en García Trobat, P., y Sánchez Ferriz, R. (coords.) (2011), El legado de las Cortes de Cádiz, Valencia, Tirant lo Blanch, pp. 285-334.

${ }_{33}$ Milton, J. (1644), A reopagítica (Discurso acerca de la libertad de expresión, sin licencias, al Parlamento de Inglaterra), México, edición año 2000 de la FCE. Disponible en URL https://ldeuba. files.wordpress.com/2013/02/libro-areopagc3adtica-john-milton.pdf

${ }^{34}$ No es el único ni mucho menos pero sí logró una resonancia especial por el foro donde desarrolló su discurso y sus inmediatos efectos. Sobre otros autores que destacan en la defensa de la libertad de prensa, $c f r$. SALDAÑa DíAz, M. ${ }^{a}$ N., «Libertad de prensa y energía política» en MilTON, J. (ed. 2000), La Areopagítica (disponible en http://pensamientopolitico.org/Descargas/ RIPP03213238. PDF). 
destruye un buen libro mata la razón misma, mata la imagen de Dios, como si dijéramos por el ojo» ${ }^{35}$.

Su convicción ante la inutilidad de la censura se transmite por la fuerza de un discurso que no omite argumento posible con el que demostrar la impertinencia y banalidad de todo intento de control de ideas y su difusión. Así, «...si pensamos en regular las prensas para con ello enderezar los modales, deberemos regular toda casta de solaces y pasatiempos, todo aquello en que los hombres hallaren su deleite. No habría que oír música... también nuestros atuendos deberían verse sometidos a licencia» ${ }^{36}$.

\section{La opinión pública, fuente de legitimidad y limite del poder ${ }^{37}$}

Los siglos XVIII-XIX representan el tiempo de asentar la idea de libertad sin que quepa aún concebir siquiera la información en el aludido sentido poliédrico en el que hay, también, deberes públicos; es el tiempo de la libertad en todos los ámbitos como eje de las nuevas luces como Stuart Mill acierta a valorar siendo su obra un fenomenal alegato en defensa del pluralismo político fundamentando la importancia de la libertad de expresión en razones diversas sobre las que concluye: «En definitiva, — nunca podemos estar seguros de que la opinión que tratamos de ahogar sea falsa, y si lo estuviéramos, el ahogarla sería también un mal... Negarse a oír una opinión, porque se está seguro de que es falsa, equivale a afirmar que la verdad que se posee es la verdad absoluta. Toda negativa a una discusión implica una presunción de infalibilidad».

Cosa distinta, sin embargo, es el «fruto político» que el concreto ejercicio de la libertad (aún solo «de prensa») irá madurando: la opinión pública. No en vano, entre las nuevas ideas que dan vida al nuevo orden liberal, la opinión pública se invoca como fuente de legitimidad secular en oposición a la religiosa que había presidido toda la política precedente. Mesonero Romanos, que lleva a cabo un detallado análisis de la prensa (del «monstruo de cien lenguas apellidado la prensa periódica») explicaba el nuevo fenómeno como especie de «sacerdocio» que desempeñaban los periodistas, «nueva potencia que quita y pone leyes...» (cuyas) ... armas no son otras que una resma de papel y una pluma bien cortada. $\mathrm{Y}$, sin embargo, ... con armas de tan dudoso temple, el periodista es una potencia

${ }^{35}$ Cfr. Saldaña Díaz, M. ${ }^{\mathrm{a}}$ N., op. cit., p. 12.

36 Ibid, pp. 44-45.

37 Sobre las contrapuestas reacciones frente al nuevo fenómeno cfr. SEvilla ANDrÉs, D. (1975). Los orígenes de la crítica social en España (1800-1856), Valencia, Catedra Fadrique Furió Ceriol. 
que quita y pone leyes, que levanta a los pueblos a su antojo, que varía en un punto la organización social... ${ }^{38}$. Desde la perspectiva de la experiencia democrática que tanto observó en América, y comentó Tocqueville, cabe también considerar la opinión pública como un límite del poder: «Es menester haber leído muy poca historia de los pueblos libres para no saber que la virtud política apenas se encuentra en quienes los conducen, y que la ambición de los mismos, su versatilidad y su egoísmo casi nunca tuvieron más límite que el impuesto por la opinión» ${ }^{39}$. Y con mayor claridad si cabe, por su directa referencia al medio al que Burke bautizaba en el parlamento inglés en 1787 como el «Cuarto poder», «the Fourth estate», que atribuía el político a la prensa: «En nuestros días, un ciudadano a quien se oprime no tiene más que un medio para defenderse...y es el que le ofrece la prensa... La prensa es por excelencia el instrumento democrático de la libertad» ${ }^{40}$.

En definitiva, ¿Qué son sino diferentes formas de limitación del poder cuantas declaraciones hemos mencionado hasta aquí? La diferencia entre las limitaciones «parciales» del Medioevo y la posterior proclamación de las grandes declaraciones también es notable desde esta perspectiva pues en estas, como primera expresión del Estado de Derecho, es todo el poder el que se somete a la ley. Hay, pues, en las modernas Declaraciones de derechos un punto de inflexión decisivo que comporta el cambio de fundamentación jurídica y, por consiguiente, de legitimidad política.

\section{DECLARACIONES DE DERECHOS DE FINAL DEL XVIII, EL UMBRAL DEL NUEVO ORDEN POLÍTICO}

Tras lo dicho es obvio que el reconocimiento de derechos, en sí mismo, no es lo determinante; lo decisivo es la significación política que se va consolidando y que lleva a contraponer los documentos medievales mencionados a los que aparecerán, como Declaraciones de Derechos (en mayúscula), en el último tercio del siglo XVIII.

\footnotetext{
38 Mesonero Romanos, R. (1955), Escenas matritenses. Madrid, Aguilar, 1955, p. 769.

39 Cartas sobre la situación interior de Francia (en Tocqueville, Alexis de: Discursos y escritos políticos. CEPC 2005 pp. 97 y ss).

${ }^{40}$ No está documentada la atribución al político inglés Burke aunque es compartida la idea por muchos; el propio Oscar Wilde en magnífica cita [Wilde, Oscar (February 1891)]. «The Soul of Man under Socialism». Fortnightly Review 49 (290): 292-319, afirma que «In old days men had the rack. Now they have the Press. Somebody — was it Burke? — called journalism the fourth estate. That was true at the time no doubt. But at the present moment it is the only estate. It has eaten up the other three. The Lords Temporal say nothing, the Lords Spiritual have nothing to say, and the House of Commons has nothing to say and says it. We are dominated by Journalism». Citado por De Esteban, J. (1997). «Los medios de comunicación como control del poder», en Revista de Derecho Político, núm. 42, p. 13.
} 
Pues si aquellos otorgan, las declaraciones liberales burguesas, por el contrario, reconocen derechos con pretensión de universalidad coherente con la formulación de la idea de nación una, y con la idea que preside tales declaraciones modernas: todos los hombres nacen libres e iguales... Frente a la concesión por el rey (a grupos con capacidad de pactar), son los nuevos poderes constituyentes quienes redactan las declaraciones reconociendo (y no concediendo) la natural igualdad y libertad de todo hombre y dictando las nuevas constituciones que, no en vano, son impuestas al monarca...

Pero a la hora de enjuiciar el constitucionalismo como fenómeno en el que el documento fundamental escrito adquiere una relevante significación política lo importante es que en él se contienen derechos y deberes de los ciudadanos porque está asentándose un nuevo orden político derivado de la filosofía liberal que llevará hasta la afirmación de que todos los hombres nacen libres e iguales. Sobre la novedad precisa Dippel: «Los delegados de Virginia de 1776... deliberadamente introdujeron un lenguaje nuevo: «Una declaración de derechos hecha por los representantes del buen pueblo de Virginia, congregados en convención general y libre; cuyos derechos pertenecen a ellos y a su posteridad, como la base y fundamento de gobierno». Este es un documento completamente nuevo, que emplea un nuevo y audaz lenguaje. Fue una «declaración de derechos», no un documento subjetivo declarando derechos, y fue establecido por «los representantes del [...] pueblo», quienes fueron «congregados en convención general y libre», y no en una asamblea cualquiera, con una equívoca legitimización-realidad, la Declaración de Derechos de Virginia no fue el primer documento constitucional de la Revolución Americana. Fue precedida por la Constitución de New Hampshire del 5 de enero de 1776, y por la Constitución de Carolina del Sur de 26 de marzo de 1776. Pero el lenguaje de estos dos documentos se parece mucho más al Bill of Rights inglés, el lenguaje de los derechos antiguos y de las libertades violentadas, pero rescatadas para ser restauradas» ${ }^{41}$.

\section{La libertad de expresión en el primer constitucionalismo ${ }^{42}$}

$Y$ es justamente en este nuevo orden en el que los derechos y libertades son un elemento axial ${ }^{43}$, donde la libertad de expresión (entonces solo de prensa)

41 Dippel, H. (2005), Constitucionalismo moderno. Introducción a una historia que necesita ser escrita, núm. 6-2005, septiembre, pp. 181-199 disponible en http://app.vlex.com/\#vid/41835727

42 Para una completa panorámica de todo el constitucionalismo español (que abarca incluso el régimen franquista), cfr. Torres, A., y Navas, F., en Torres del Moral, A. (dir), Libertades..., ya cit., pp. 49-67.

43 No se olvide el contenido del artículo 16 de la Declaración francesa de 1789: «Toda sociedad que no tiene sus poderes divididos y los derechos de sus ciudadanos reconocidos y garantizados, no tiene Constitución». 
cobra todo su sentido político aunque aún falten nuevas dimensiones que deban ir asentándose. Así, rezaba la Declaración de Derechos del Buen Pueblo de Virginia, de 12 de junio de 1776 (e independencia 4 julio 1776), n. 12 «Que la libertad de prensa es uno de los grandes baluartes de la libertad y no puede ser restringida jamás a no ser por gobiernos despóticos». Y con carácter mucho más amplio se expresa en Francia la Declaración de los Derechos del Hombre y del Ciudadano, 26 de agosto de 1789, cuyo artículo 11 disponía: «La libre comunicación de los pensamientos y de las opiniones es uno de los derechos más preciados del hombre, todo ciudadano puede, por tanto, hablar, escribir e imprimir libremente, salvo la responsabilidad que el abuso de esta libertad produzca en los casos determinados por la ley».

Sin embargo, atendiendo a la filosofía individualista que la inspira, alejada de la significación social que adquirirá con el tiempo, habrá que esperar para que se de el salto que permita considerar la comunicación como derecho y no solo como libertad. Naturalmente, la sociedad aún no ha evolucionado tanto como para llevar a cabo el gran cambio; y no es poco el que la invocación de la opinión pública refleja y la proclamación de la libertad de imprenta puede comportar aunque en sus inicios, como Larra denunciaba, los efectos hubieran de tardar hasta el punto de considerar su invocación un engaño colectivo: «A mi me da qué hacer la libertad de imprenta; yo soy el único a quien da qué hacer, pero, en fin, me da. Habla la Reina, y se hace lenguas de la libertad de imprenta; hablan los ministros, y para ellos no hay altar donde ponerla; ... Y hablo yo y digo, como don Basilio en la ópera de mi tocayo: “¿A quién engañamos, pues, aquí? ¿Quién diantres impide que la establezcan?” ${ }^{44}$.

\section{El derecho a la información madura extramuros del Derecho que solo lo asumirá en el siglo $\mathrm{XX}$}

Con el tiempo se irán desplegando todas las virtualidades del cambio de perspectiva (de la idea de libertad a la de derecho), pero como ya dijimos, habrá que esperar a la segunda postguerra mundial, al periodo en que se consolide la corriente constitucional democrática en algunas de cuyas Constituciones el derecho a la información adquiere ya todo su sentido como legitimador del sistema en términos que previamente han ido cuajando en aportaciones doctrinales entre las que hemos

44 Las citas de LARra: «Dios nos asista», U, pp. 191 y 192, respectivamente. Disponible en la Biblioteca virtual Cervantes: http://www.cervantesvirtual.com/portales/academia_mexicana_ de_la_lengua/obra-visor-din/dios-nos-asista-tercera-carta-de-figaro-a-su-corresponsal-en-paris--0/ html/ff811892-82b1-11df-acc7-002185ce6064_2.html 
apuntado algún ejemplo a los que se ha de sumar de modo especial la doctrina social de la Iglesia ${ }^{45}$. El derecho a la información esperará a la última corriente constitucional democrática en lo que se refiere a su formalización en textos fundamentales. Incluso su cabal comprensión por parte de la doctrina se hace esperar a la maduración de una idea democrática que solo se alcanza en la segunda mitad del siglo $\mathrm{xx}$, tras las penosas experiencias de su primera mitad vividas en Europa ${ }^{46}$. Porque no basta que se haya instalado la filosofía liberal en los nuevos Estados a caballo del siglo XVIII y el XIX; ni que, cuando hayan evolucionado en democracias parlamentarias, se doten de contenido social en el primer tercio del xx. Habrá que esperar también a que se haya extendido el sufragio universal como expresión de igualdad política y a que la democracia quede consolidada. Ello exige una concepción de la ciudadanía participativa y activa, interesada en las cuestiones públicas que ya no se reducen al interés de las elites; solo así podemos hablar del derecho a la información propio de un sujeto universal, como todos los fundamentales, y más allá, por consiguiente, del que los profesionales de la información podían invocar. Por ello diría Voyenne que «es sorprendente constatar que la noción del derecho a la información, aunque coextensiva al conocimiento y, por tanto, a la Humanidad desde sus orígenes, no haya emergido más que con una sorprendente lentitud en la conciencia social» ${ }^{47}$.

\section{EL TARDÍO RECONOCIMIENTO DEL DERECHO A LA INFORMACIÓN}

En 1946 el director de la Agencia France Presse (Paul-Louis Bret) menciona ${ }^{48}$ por vez primera, «el derecho al hecho» con ocasión de exigir del Estado ayudas que faciliten la accesibilidad de las agencias y profesionales a la información ${ }^{49}$. Poco después, en 1949 encontramos la formulación del derecho a la información en documentos constitucionales $^{50}$, en Alemania bajo la ocupación americana (en dos Lander y en la Ley Fundamental de Bonn): en Baviera se reconoció a la prensa «un derecho a las

45 Cfr. SÁnChez Ferriz, R., El derecho a ..., ya cit., pp. 115 y ss.

46 Devirieux, C. J., Manifeste Pour le Droit à..., ya cit., p. 25) sostiene que en Nuremberg se juzgó y condenó a dirigentes nazis, no por ser culpables de atrocidades sino porque durante 15 años incitaron a individuos y grupos a cometerlas en nombre del sistema condicionando a todo el pueblo alemán.

47 Voyenne, Bernard, Le Droit à l'information, Paris, Aubier-Montaigne, 1970, p. 109.

48 Cit. por Devirieux, C. J., Manifeste pour ... ya cit. Pág. 45.

49 Ibid, p. 31.

${ }^{50} \mathrm{Cfr}$. Todos los textos constitucionales que consagran la libertad de expresión se enumeran en Morange, J. (1993), La liberté d'expression, Paris, Presses Universitaires de France, pp. 114 y ss. 
informaciones dimanantes del Estado», y en Hesse quedaba formulado «el deber de las autoridades de transmitir a la prensa las informaciones solicitadas». Desde luego era una primera aproximación sin llegar a formular el derecho con carácter univer$\mathrm{sal}^{51}$. Mayor aproximación se llevaría a cabo en el artículo 5 de la Ley Fundamental de Bonn al decir en su artículo 5, párrafo 1: «Todos tienen el derecho a expresar y difundir libremente su opinión por medio de la palabra, por escrito y por la imagen, y de informarse sin trabas en las fuentes accesibles a todos. La libertad de prensa y la libertad de información por radio y cinematografía están garantizadas. No se ejercerá censura...» ${ }^{52}$. También se consideró como una de las primeras Constituciones que llegaron a formular tal derecho la yugoslava ${ }^{53}$. Ciertamente, existen aproximaciones a la idea de la información como derecho en estos textos pero no llega a formularse como en el artículo 5 de la Constitución alemana que hemos trascrito ${ }^{54}$. Solo en él se apunta al sujeto universal no solo activo sino también pasivo: «todos tienen derecho... de informarse sin trabas...», aunque tampoco en este texto se halla una comprensión cabal del derecho a ser informado que sí veremos infra en la Constitución portuguesa, más de dos décadas después.

\section{Textos internacionales}

En el mismo período de postguerra se llevan a cabo nuevas aproximaciones en documentos internacionales de primer nivel. En particular, es de destacar la

${ }^{51}$ SÁnchez Ferriz, R. (1973), El derecho a ..., op. cit., p. 110.

52 Sobre la significación de este precepto como punto de inflexión de todo lo anterior cfr. Desantes, J. M. ${ }^{a}$, La función..., op. cit., p. 80. Un reciente estudio, puede verse en Tenorio, P. J. y Elías Méndez, C. (2014). «La libertad de expresión en la Ley Fundamental de Bonn y el la jurisprudencia del Tribunal constitucional federal alemán», en TENORIO SÁNCHEZ, P. J. (2014) (dir.) La libertad de expresión. Su posición preferente en un entorno multicultural, Madrid, Wolters KLuwer, pp. 193 y ss. Debe, no obstante, subrayarse la predominante situación en el artículo constitucional de referencia de la libertad de opinión sobre la de información.

53 SÁnchez Ferriz, R. (1973), El derecho a ..., op. cit., p. 110. Sin embargo, la Constitución italiana no llegó a introducir la más mínima referencia a la información quedando en una formulación liberal reconducida a la libertad de manifestación del pensamiento. Por todos, Mezzetti, L. (2014), «La liberad de manifestación del pensamiento y sus límites en el ordenamiento constitucional italiano», en Tenorio Sánchez P. J. (2014) (dir.) La libertad de expresión.., op. cit., pp. 269 y ss.

${ }^{54}$ Al Tribunal federal se debe la construcción dogmática del artículo 5 en el que, según ya hemos dicho, predomina la protección de la libertad de opinión pero ello no obstante es clara la segunda afirmación del precepto, el derecho de informarse, sobre el que el Tribunal ha exigido el deber de la verdad. Cfr. Tenorio, P. J. y Elías Méndez, C. (2014). La libertad de expresión en la Ley Fundamental de Bonn..., op. cit., p. 200. 
Declaración Universal de 1948 y en particular su artículo 19, en el que se lee: «Todo individuo tiene derecho a la libertad de opinión y de expresión; este derecho incluye el de no ser molestado a causa de sus opiniones, el de investigar y recibir informaciones y opiniones, y el de difundirlas, sin limitación de fronteras, por cualquier medio de expresión». A decir verdad, en esta gran Declaración se sigue con los intentos de aproximación al concepto, más por la vía de la enumeración de las diversas facultades que se van reconociendo a partir de la libertad de expresión, que por la cabal comprensión de lo que realmente sea el derecho a la información ${ }^{55}$. Pues, como recordaba Desantes, es cierto que en la Declaración del 48 existen elementos suficientes para construir el derecho a la información (vinculando e interpretando sistemáticamente el artículo 19 con el 28 y el 21), pero no lo es menos que adolece jurídicamente de los problemas de eficacia jurídica de todo documento internacional ${ }^{56}$; ello sin perjuicio de su extraordinaria fuerza moral y del importante paso que representa (solo superado por el Convención de Roma por lo que en términos de eficacia supone el Tribunal Europeo de Derechos Humanos). No cabe negar que existen los elementos (como se acaba de ver en Corredoira) extrayendo del artículo 19 todas las posibilidades de ser aplicado, incluso en la presente sociedad de la información, pero no puede negarse que sigue faltando la formulación expresa del derecho a la información. Tal vez por ello Voyenne advertía sobre el equívoco del texto: «L'équivoque subsiste toutefois sur le fait de savoir s'il s'agit seulement de ne pas entraver cette liberté ou, ce qui est très différent, de la promouvoir» ${ }^{57}$.

Y lo mismo cabe decir de la Convención Europea para la Protección de los derechos humanos y de las Libertades públicas (CEDH), de 4 de noviembre de $1950^{58}$, cuyo artículo 10 sigue de cerca la técnica de la DUDH aunque según se acaba de decir, es decisivo el paso dado en la búsqueda de la eficacia; lo que, en un documento internacional, resulta extraordinario. Ha de subrayarse también que este artículo 10 añade un segundo párrafo cuyo interés ya se ha destacado en otras ocasiones precisamente para poner de relieve las peculiaridades de

55 Sobre las insuficiencias del artículo 19 de la Declaración Universal SÁNCHEz FERrIz. El derecho a..., ya cit., p. 112 y ss. No obstante, el paso dado es importante y parte de la doctrina considera que ya se contiene en tal precepto el derecho a la información. Así, Corredoira y Alfonso, L. (2006), «Lectura de la Declaración Universal de Derechos Humanos de 1948 en el paradigma de la nueva Sociedad de la Información. Estudio específico del artículo 19», en CoTiNO HuEso, L. (2006), Libertad en Internet. La Red y las libertades de expresión e información, Valencia, Tirant Lo Blanch, pp. 57 y ss.. passim.

56 Desantes Guanter, J. M. ${ }^{\text {a }}$ (1977), Fundamentos..., ya cit., pp. 45 a 52.

57 Op. cit., p. 63.

58 Texto en la web en español http://www.echr.coe.int/Documents/Convention_SPA.pdf 
las libertades públicas en tanto que son derechos que pueden causar daños en otros derechos fundamentales ${ }^{59}$.

Se puede deducir de los dos preceptos de carácter internacional ahora mencionados una amplia libertad para informar e informarse pero falta aún explicitar lo esencial del derecho a la información, su condición de democraticidad que implica a toda la ciudadanía no solo como sujeto activo del derecho a informar sino también como sujeto pasivo o acreedor a una información veraz de naturaleza pública que justamente le pertenece por su papel activo en la democracia. Y lo curioso es que casi dos décadas después, en el Pacto internacional de los derechos civiles y políticos (de 16 de diciembre de 1966) sigue sin avanzarse en la conceptuación formal del derecho por cuanto el mismo se mantiene en términos similares a los de la Declaración Universal de 1948 y de la Convención europea de 1950. Con todas sus deficiencias, pero son estos documentos los que cierran el período liberal que nos aportó, sí, la libertad de informar... pero no para todos sino para los más fuertes: «La libertad de informar proclamada por el liberalismo es la libertad para el fuerte, que poco aprovecha para el ciudadano en general» ${ }^{60}$.

\section{Maduración de la idea en la doctrina social de la Iglesia}

Aun habrá que esperar una década más para que podamos encontrar totalmente constitucionalizado el derecho a la información; hasta que ello ocurra no falta su cabal comprensión pues puede encontrarse en muchos documentos de doctrina social de la Iglesia Católica en la que se fue formulando. En ellos hallamos desde lo que podríamos llamar «despenalización» de la prensa, a partir de León XIII, hasta las expresas declaraciones del Concilio Vaticano II en defensa del derecho estudiado ${ }^{61}$; y en tal proceso ha de destacarse la utilización del término información, por vez primera, por Pío XII y en términos decisivos para la comprensión de la misma. Pero sin duda las expresiones de mayor interés las encontramos en la encíclica Pacem in Terris (de 11 de abril de 1963) hasta el punto de poder afirmar, tal como lo hace Terrou, que el derecho a la información, como derecho «a ser informado» es en dicho documento donde recibe por vez primera su formulación expresa ${ }^{62}$ pues en su párrafo 12 se lee: «el hombre exige,

\footnotetext{
59 SÁnchez Ferriz, R. (1995), Estudio..., op. cit.

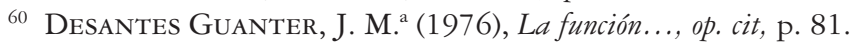

${ }^{61}$ Los textos que se citan en Iribarren, J., y Gutiérrez García, J. L. (1968), Cinco grandes mensajes, Madrid, B. A. C.

${ }^{6}$ Así lo sostiene sin ningún género de duda Terrou, F. (1970), La información, cit., p. 8.
} 
además, por derecho natural el debido respeto a su persona... y, finalmente, disponer de una información objetiva de los sucesos públicos». Son otros muchos los textos que nos permiten afirmar la existencia de un cuerpo de doctrina previo al que después se conformará en los documentos constitucionales y en la interpretación de los Tribunales Constitucionales. Así, en la Gaudium et Spes podemos hallar la mejor acepción de las que se formularon en aquellos años y que valoramos especialmente por ubicar el derecho humano en el ámbito de lo público: «...todo esto exige también que el hombre, con tal que respete el orden moral y la utilidad común, pueda libremente buscar la verdad y exponer y divulgar su opinión, y cultivar cualquier forma de arte y ser, finalmente informado de los acontecimientos públicos» ${ }^{63}$.

\section{FORMULACIÓN CONSTITUCIONAL DEFINITIVA EN LOS AÑOS 70}

Volviendo a la afirmación de la lentitud con que se formula el derecho a la información, hay que decir que hasta la década de los 70 no alcanza una conceptuación definitiva y a nivel constitucional. Siendo escasos los textos de primer rango que han llegado a la formulación expresa (de forma completa el portugués y en una primera aproximación el texto alemán que se acaba de citar) debe observarse que la labor de los Tribunales Constitucionales ha venido a completar y desarrollar los contenidos implícitos como veremos que ha ocurrido en España y antes ya sucedió en Italia ${ }^{64}$. Sobre la aparición sucesiva de este derecho en los textos europeos cabe destacar: 1. La Constitución portuguesa de 1976, en cuyos artículos 37 a 40 formalizan el reconocimiento más completo del derecho a la información en el máximo nivel normativo. Pero sobre todo es un artículo, el 48.2. el que proclama que «todos los ciudadanos tienen el derecho de ser esclarecidos objetivamente» sobre los actos del Estado, entidades y asuntos públicos. Y, 2. la Constitución española de 1978 donde el derecho a la información aparece junto a (pero también al margen de) la libertad de expresión. Debe subrayarse esta afirmación que podríamos llamar «dualista» a diferencia de la interpretación monista que se contiene en el artículo 19 de la DUDH o la del

63 Otros documentos de interés en SÁNCHEz FERriz, R. (1974), El derecho a ..., cit., p. 119-120.

64 Entre tantos, recientemente, MezzetTi, L. (2016), «La libertad de manifestación del pensamiento y sus límites en el ordenamiento constitucional italiano», en TENORIO SÁNCHEZ, P. J. (dir.) (2014), op. cit., p. 284: sobre el «derecho general a la información, a comienzo de los años 70, el TCi (STCi 105 de 1972) reconoció la existencia de un interés general a la información, indirectamente protegido por el artículo 21 de la Constitución...». 
artículo 14 del CEDH, así como de la interpretación realizada por el TCi derivada del artículo 21 de la Constitución italiana (1947) que, según hemos visto supra, solo reconoce abiertamente la libertad de manifestación del pensamiento ${ }^{65}$.

Desde luego el texto español no siguió el ejemplo portugués en lo que se refiere a la claridad conceptual y a las distinciones terminológicas a que nos acabamos de referir, ni tampoco en la completitud del texto vecino que no dejó ningún elemento importante a desarrollo posterior. Pero tampoco se sumó a la opción monista del artículo 19 de la DUDH (de cuya capacidad para dar cobertura a las nuevas necesidades informativas no cabe dudar según Corredoira ${ }^{66}$ ). En todo caso, por más que no quepa negar el reconocimiento formal de dos libertades distintas, la de expresión (en art. 20.1, a) y la de información (en art. 20.1, d), no hay en el texto constitucional claridad alguna sobre la relación entre las dos libertades mencionadas que solo se fue determinando a partir de los pronunciamientos del Tribunal Constitucional. Ciertamente, es el TC el que ha aclarado el ambiguo y complejo artículo 20 de suerte que hoy ya no existen las dudas que se plantearon en los primeros años del régimen constitucional de las que bastará recordar aquí solo dos: en primer lugar, sobre si nos adscribíamos al monismo o al dualismo según el cual la libertad de expresión y la de información son dos derechos independientes; en segundo lugar, sobre las consecuencias que sobre la concreta posición de los profesionales de la información en el sistema informativo habría de tener el párrafo 1, d) del artículo 20. Ambas cuestiones fueron resueltas sin grandes discrepancias y, además, en una interpretación que las resuelve en forma complementaria.

Lo bien cierto es que nuestro ordenamiento se ha decantado abiertamente por una interpretación dualista ${ }^{67}$ en cuya virtud la libertad de expresión y la de

65 Así, en STC 112 de 1993 se lee: «la Constitución en el artículo 20 reconoce y garantiza a todos la libertad de manifestar el propio pensamiento con cualquier medio de difusión y tal libertad comprende tanto el derecho de informar como el derecho a ser informados, los cuales, por razón de su contenido, se traduce directamente en derechos subjetivos del individuo de carácter absoluto...» (cit. MezzetTi, L. (2016). « La libertad de manifestación del pensamiento y sus límites en el ordenamiento constitucional italiano», en TENORIO SÁnCHEZ, P. J. (dir.), op. cit., p. 285.

66 Corredoira y Alfonso, L. (2006), Lectura de la Declaración..., op. cit.

${ }^{67}$ La doctrina del Derecho de la información (Desantes, J. M., y Soria SAIz, C, Los límites de la información: la información en la Jurisprudencia del Tribunal Constitucional, Asociación de la Prensa de Madrid, 1991), actualizada por Ignacio Bel (El derecho..., ya cit., p. 169) se ha mostrado siempre contraria a la interpretación dual del artículo 20; como también la obra de González Ballesteros, T. (2015), en «Doctrina del Tribunal Constitucional en materia de Libertad de Expresión y de Información», en Bel Mallén, I., y Corredoira, L. (2015) (editores), El Derecho de la Información, op. cit., pp. 783-859. Sin embargo, tal como con claridad precisa Gómez Sánchez (op. cit., p. 1236 ss) ambas libertades son elementos necesarios en la nueva sociedad de la información. 
información no son susceptibles de ser confundidas en la medida en que difieren por su objeto. Cabe resumir la construcción española del derecho a la información en forma no muy diversa de la ya consolidada en nuestro entorno «democrático occidental»: el derecho a la información es el derecho a la noticia, en realidad, a los hechos noticiables de interés público (y por consiguiente, con exclusión de los de naturaleza privada); y, ello es así, a diferencia de lo que se reconoce y garantiza a través de la libertad de expresión que no es otra cosa que la libertad de manifestar las propias opiniones, ideas y pensamientos sin más limitación que el insulto o la ofensa gratuita ${ }^{68}$. Sin embargo, no podemos acabar estas referencias a la consagración del derecho a la información en el máximo nivel normativo sin mencionar la Carta europea de los derechos fundamentales firmada en Niza el año 2000 cuyo artículo 11, bajo el epígrafe de «Libertad de expresión y de información» no solo consagra la importancia de esta sino que se adhiere a la concepción monista del artículo 19 de la Declaración universal de 1948 al expresarlo así abiertamente en su párrafo 1: «1. Toda persona tiene derecho a la libertad de expresión. Este derecho comprende la libertad de opinión y la libertad de recibir o de comunicar informaciones o ideas sin que pueda haber injerencia de autoridades públicas y sin consideración de fronteras. 2. Se respetan la libertad de los medios de comunicación y su pluralismo» ${ }^{69}$.

Evidentemente, pese a lo avanzado en el tiempo de la Carta, cuando ya definitivamente se ha conformado el derecho a la información tanto en lo doctrinal y en los textos constitucionales como, sobre todo, a través de las decisiones jurisprudenciales de los Tribunales Constitucionales de nuestro ámbito político y social, la Carta es extraordinariamente conservadora al sumarse a una concepción que fue novedosa a mitad del xx pero que hoy resulta algo pobre. Ello sin ignorar que el segundo párrafo, al proclamar la libertad de los medios de información, parte del derecho a la información que constituye el fundamento de aquella aun cuando este no se mencione expresamente. La naturaleza internacional del texto (por más que se halle en camino de la constitucionalización de la Unión) puede explicar su pacata configuración, a modo de forzada bisoñez cuando se está usando un concepto, si no caduco, sí superado en otras sedes. Pero sí hay alguna razón, o puede haberla, de mayor coherencia de dicho texto precisamente por su naturaleza internacional y que conecta con la naturaleza política del derecho a la información que hemos visto madurar en el Constitución por-

68 SÁnchez Ferriz, R., Delimitación de las libertades..., ya cit., passim. La recopilación de toda la jurisprudencia al respecto hasta 2014, en González Ballesteros, Teodoro, en Doctrina..., ya cit.

${ }^{69}$ Cfr. el marco normativo en que insertar el precepto transcrito, en GómEZ SáNCHEZ, Y., ya cit. p. 1226. 
tuguesa: justamente, en un texto dirigido a 28 Estados mucho más no se puede consagrar si consideramos la estrecha relación que el derecho a la información, en su faceta publica, supone entre sus destinatarios (la propia ciudadanía) y sus obligados (los poderes públicos).

\section{A MODO DE RECAPITULACIÓN. EL SIGLO XXI: LA SOCIEDAD DE LA INFORMACIÓN}

\section{Sociedad de la información ¿del derecho a informarse a la saturación informativa?}

De la información-comunicación como elemento configurador de toda comunidad política (con planteamientos de orden antropológico y filosófico que ya encontramos en el pensamiento clásico al que se aludió supra) hemos pasado a su configuración como derecho fundamental, por obra de la democratización, y, hoy, a una sobreabundancia informativa de la que, por obra de las tecnologías, se diría que casi hemos de defendernos en la medida en que se nos impone por el sistema de alertas de todo orden. En efecto, la sociedad de la información que hace poquísimos años comportaba una invocación del acceso de todos al uso de internet, hoy se ve concluida por obra de los teléfonos móviles y del uso masivo de las redes sociales. Como se acaba de afirmar la sociedad de la información ya no es una aspiración sino una realidad cuyo desarrollo se impone por mor de los intereses económicos a los que obedece y por un cambio de época de tan grande dimensión como lo fue la imprenta a partir del siglo XV. Y respecto de la ciudadanía cabría decir que la nueva situación se impone creando cierta desigualdad entre quienes hacen uso de las tecnologías y quienes renuncian a ellas o simplemente se sienten incapaces. La nueva exigencia política de transparencia y acceso a los documentos públicos no desmiente esta desigualdad funcional aunque sí redunda en una mayor democratización ${ }^{70}$.

Desde la perspectiva doctrinal se observa la culminación del fenómeno informativo cuando se invoca como deber del Estado — afirma Corredoira- el «garantizar que los ciudadanos tengan el máximo de oportunidades para formar parte de esa Sociedad de la Información. Esta es, entiendo, desde el punto de vista del derecho humano a la información, la clave» ${ }^{71}$. Visto así, estamos ante

70 Cfr. SÁnchez Ferriz R., Valoración constitucional del marco juridico-politico abierto por la ley 9/2013, de transparencia, derecho de acceso a la información pública y buen gobierno, en Cuadernos Constitucionales de la Cátedra Fadrique Furió Ceriol, en prensa.

71 Corredoira y Alfonso, L. (2006). Lectura de la Declaración Universal...., ya cit., p. 71. 
una enorme expansión de la comunicación pues el fenómeno internet ha sido capaz de subsumir todo tipo de soportes informativos previos y, al llegar a identificarse él mismo como «vía pública», se llega a asimilar la libertad de acceso a internet con la misma libertad personal de todo ser humano. Decía Corredoira que el postulado del artículo 19 de ONU era suficiente declaración en el que caben todas las innovaciones tecnológicas y los derivados de su relación con el poder. Trascurridos 20 años desde la explosión de Internet en el ámbito comercial y privado (calendado en el año 1996) no parece que, a priori, «haya necesidad de otros requisitos más, pero sí que se ejerzan los derechos a investigar, recibir y difundir información de modo más completo, más inclusivo, eliminando barreras (tecnológicas, normativas, etc.) y, sobre todo, que el poder ejecutivo, legislativo y judicial se crea que el público, sus ciudadanos y administrados son los titulares del derecho a saber, a conocer, y que tan solo razones de gravedad (muy extraordinarias) como la seguridad o la intimidad de las personas puedan justificar la opacidad o publicidad parcial de información relevante». ${ }^{72}$

\section{Del derecho a la información al derecho a poder navegar por la red}

El problema hoy no se plantea ya en términos de reconocimiento formal ni de construcción jurídica como en el siglo xx, sino que todos los elementos conceptuales que en ese proceso se han ido configurando, siguen vigentes aun cuando el marco de actuación social ha variado ostensiblemente y, obviamente, la estructura general del fenómeno informativo se ha visto afectada por la nueva realidad. Ciertamente, siendo importante, e inexcusable como punto de partida en toda aproximación a dicho fenómeno, el conocimiento de la dogmática jurídica y del papel que en cada momento histórico han ido jugando los elementos conceptuales $^{73}$ recordados, la nueva realidad de la sociedad de la información impone sin embargo algunos cambios de perspectiva que no afectarán tanto a los

72 Corredoira y Alfonso, L., «Evolución del derecho de acceso: de la disponibilidad técnica y asequible a la Red, al acceso como forma de participación», en Cotino HuEso, L., SAHUQuillo Orozco, J. L., y Corredoira, L. (Eds.) (2015), El paradigma del Gobierno Abierto, Retos y oportunidades de la participación, transparencia y colaboración, Universidad Complutense de Madrid, 2015. ebook disponible en http://eprints.ucm.es/35859

73 La idea puede encontrarse desarrollada en un sentido más amplio (y si cabe profundo por cuanto no se limita a los principios constitucionales del ordenamiento español) en —El valor permanente de lo clásico en las ciencias de la comunicación, en Desantes GuANTER, J. M. ${ }^{a}$ (2004), Derecho a la información. Materiales para un sistema de la comunicación, Valencia, COSO, pp. 51 y ss. 
conceptos consolidados cuanto a la relación entre los distintos elementos que intervienen en el fenómeno informativo globalizado.

En este sentido, nos parecen oportunas algunas consideraciones para cerrar esta reflexión:

1. Sin duda la libertad de expresión ha alcanzado su máxima expresión, y esta vez sí para todos, gracias a la disponibilidad de la red. Y cabría decir que también de ello se beneficia el derecho a la información en la medida en que se universaliza y facilita la obtención de información de todo orden que hoy cómodamente podemos encontrar en la red. Pero esta segunda afirmación requiere de matices pues la posibilidad de hallar todo tipo de información no se corresponde exactamente con el derecho a la información sobre las cuestiones que nos afectan o de cuyo conocimiento puede depender nuestra actuación consecuente. El período electoral podría constituir un buen ejemplo de lo que se quiere expresar: la sobreabundancia de información no impide que sigamos sin conocer aquello que realmente podría interesarnos más o que desearíamos conocer para determinar el sentido de nuestro voto. Lo que, directamente, nos conduce a uno de los elementos del derecho a la información que pudo ser importante en el proceso de conformación del mismo en el siglo xx pero que hoy no parece gozar de gran predicamento por dos razones: en primer lugar, por la lógica reticencia de todo régimen democrático a los dogmatismos y, en segundo lugar, porque la red pone en manos de la ciudadanía un poderoso instrumento que no nos exime de la influencia, desmedida, de los intereses políticos y económicos que la invaden. Nos referimos al derecho a la verdad o, cuanto menos, al derecho a saber lo que nos interesa, más allá y por encima de lo que se nos quiera hacer saber, lo que impone, cuanto menos a los poderes públicos, un deber de objetividad. Se diría que el viejo derecho a la información requiere más que nunca de la capacidad de discernir, valorar y calificar un volumen ingente de información y, por consiguiente requiere de una ciudadanía bien formada viniendo a confirmar las notas característica a que hemos aludido en el epígrafe III (supra).

2. Pero también la máxima expansión del derecho y sus concretas facultades ha aportado otra modificación (una más) a este derecho que hemos bautizado de poliédrico y habría que añadir mutante. La información sigue siendo el libre flujo de noticias, ideas e opiniones, como en el siglo xx, pero además ahora se introduce un elemento técnico entonces inexistente: es la incorporación de todos al uso (y al consumo más o menos programado) de la técnica. Baste un ejemplo: si el sujeto activo de la información, minoritario y básicamente conformado en torno a las empresas de la comunicación, se correspondía con un sujeto pasivo 
universal, hoy la universalización se extiende también a los sujetos activos que interactúan a través de internet sin necesidad de profesionalización alguna.

3. La realidad tecnológica presente que conocemos como sociedad de la información ha llevado a su máxima expansión al derecho a la información pero no ha sido capaz de hacerlo sin apartarse de su configuración; se han ido ideando e invocando otros derechos supuestamente nuevos, aunque en realidad no son sino simples facultades, facetas o aspectos del derecho a la información que, en la medida en que se han desarrollado las vivencias democráticas ha podido ir demostrando toda su virtualidad en el ámbito político y en la consolidación democrática $^{74}$. No en vano, hoy se habla del derecho de acceso universal a internet y a cierta brecha de pobreza tecnológica que obliga a los Estados a extender los beneficios de la fibra a las zonas menos rentables... ${ }^{75}$.

En definitiva, el derecho a la información sigue siendo el eje de la participación democrática, su papel y significación no cambia aunque parece olvidarse temporalmente en tanto se instalan en el lenguaje facultades nuevas impuestas por los avances tecnológicos. Nuevas formas respecto de otros «escalones» previos: libertad de imprenta, el derecho de antena, el derecho de acceso... fueron entonces, como ahora, nuevas exigencias de una técnica en permanente cambio.

\section{BIBLIOGRAFÍA}

Abad Alcalá, L. (2015): «El derecho a la información y las libertades informativas en el ámbito europeo», en Bel Mallén, I. y Corredoira y Alfonso, L. (dirs.) (2015): Derecho de la información. El ejercicio del derecho a la información y su jurisprudencia, Madrid, Centro de Estudios Políticos y Constitucionales, pp. 69-95.

Bel Mallén, I., Corredoira y Alfonso, L. (dirs.) (2003): Derecho de la información, Barcelona. Ariel.

- (2015): Derecho de la información. El ejercicio del derecho a la información y su jurisprudencia. Madrid, CEPC.

Braud, Ph. (1968): La Notion de Liberté Publique en Droit Français, Paris.

74 Se incide abiertamente en este aspecto en SÁNCHEZ FERrIZ, R., Valoración constitucional del marco juridico-politico abierto por la ley 9/2013..., ya cit.

75 En ese sentido también ha hablado Corredoira del derecho de acceso a internet «como forma de inclusión», Corredoira y Alfonso, L., (2013). Lectura de la Declaración..., ya cit., pp. 68 y ss. 
Corredoira y Alfonso, L. (2006): «Lectura de la Declaración Universal de Derechos Humanos de 1948 en el paradigma de la nueva Sociedad de la Información. Estudio específico del artículo 19», en Cotino Hueso, L. (2006): Libertad en Internet. La Red y las libertades de expresión e información, Valencia, Tirant Lo Blanch, pp. 57 y ss.

Corredoira y Alfonso, L. y Cotino Hueso, Lorenzo (editores) (2013): Libertad de expresión e información en Internet. Amenazas y protección de los derechos personales, Madrid, Centro de Estudios Políticos y Constitucionales.

Corredoira y Alfonso, L. «Evolución del derecho de acceso: de la disponibilidad técnica y asequible a la Red, al acceso como forma de participación» en CoTINO Hueso, L. (2006): Libertad en Internet. La Red y las libertades de expresión e información. Valencia Tirant Lo Blanch.

De Esteban, J. (1996): «Medios de comunicación y Estado de Derecho», p. 466 en Ciudadanos e instituciones en el constitucionalismo actual / coord. por Asensi Sabater, J. (1996), pp. 465-488

- (1997). «Los medios de comunicación como control del poder», en Revista de Derecho Político (UNED), núm. 42, pp. 11-34.

De Vitoria, F. (1528): Lección De potestate civile, 4, Salamanca. Traducción de las lecciones de Vitoria disponibles en Internet.

Desantes Guanter, J. M. a (1977): Fundamentos del Derecho de la Información, Confederación Española de Cajas de Ahorros. Memoria de Cátedra.

- (1976): La función de informar. Pamplona, Universidad de Navarra.

Desantes Guanter, J. M. a, Bel, I., Cousido, P. Corredoira, L., y García, R. (1994): Derecho de la Información Vol. 2. Los mensajes informativos, Madrid, Colex

- (1999): Francisco de Vitoria, precursor del Derecho de la Información, Madrid, Fundación de la Comunicación Social.

- (2004): Derecho a la información. Materiales para un sistema de la comunicación. Valencia, COSO.

Devirieux, C. J. (2009): Manifeste Pour le Droit à L'Information: De la Manipulation à la Législation, Presses de l'Université du Quebec.

Dippel, H. (2005): Constitucionalismo moderno. Introducción a una bistoria que necesita ser escrita, Núm. 6-2005, Septiembre, pp. 181-199 disponible en http://app. vlex.com/\#vid/41835727

Fernández de Marcos, Ramón J., «A propósito de algunas relecciones de Francisco de Vitoria», Revista de Derecho UNED, núm. 4, 2009.

Fisher, J. (2015): «Why Magna Carta still matters today», publicado con motivo de los 800 años de su promulgación disponible en https://www.bl.uk/magnacarta/articles/why-magna-carta-still-matters-today

García Trobat, P. «El manual mata la cátedra»; en Romano, A. (cur.) (2015): Dalla lectura all' e-learning, Bologna, CLUEB, pp. 227 y ss. 
García Trobat, P. (2011): La libertad de imprenta, aliada de la revolución, en GARCía Trobat, P. y Sánchez Ferriz, Remedio (coords.) (2011), El legado de las Cortes de Cádiz, Valencia, Tirant lo Blanch, pp. 285-334.

Gómez SÁnchez, Y. «La Sociedad de la Información en Europa», en Torres del Moral, A. dir. (2009): Libertades informativas, COLEX, Madrid, pp. 1215-1249.

GonzÁlez Ballesteros, T. (2015): «Doctrina del Tribunal Constitucional en materia de Libertad de Expresión y de Información», en Bel, I. y Corredoira, L.(2015): Derecho de la Información, Madrid, CEPC, pp. 783-859.

Iribarren, J., y Gutiérrez García, J. L. (1968): Cinco grandes mensajes. Madrid, B. A. C.

Mesoneros Romanos, R. (1955): Escenas matritenses. Madrid, Aguilar.

MezzetTi, L. (2014): «La liberad de manifestación del pensamiento y sus límites en el ordenamiento constitucional italiano», en Tenorio Sánchez P. J. (2014), (dir.) La libertad de expresión Su posición preferente en un entorno multicultural, Fundación Wolters Kluwer España, Madrid, 2014, pp. 269 y ss.

Milton, J. (2000): Aeropagítica (Discurso acerca de la libertad de expresión, sin licencias, al Parlamento de Inglaterra). Mexico, FCE.

Morange, J. (1993): La liberté d'expression. Paris, Presses Universitaires de France.

Robinson, J. (1979): Libertad y necesidad. Introducción al estudio de la sociedad. 8. edic. Madrid, Siglo XXI.

Saldaña Díaz, M. ${ }^{a}$ N. (2007): "Libertad de prensa y energía política en la Aeropagita de Milton», en Revista Internacional de Pensamiento Político, II época, vol. II. Pp. 211-235. Disponible en http://pensamientopolitico.org/Descargas/ RIPP03213238. PDF

SÁnCHEZ Ferriz, R. (1974): El derecho a la información. Valencia, Cosmos.

- (1995): Estudio sobre las libertades. Valencia, Tirant Lo Blanch.

- (2004): Delimitación de las libertades informativas. Valencia, Tirant lo Blanch.

Sevilla Andrés, D. (1975): Los orígenes de la crítica social en España (1800-1856). Valencia, Catedra Fadrique Furió Ceriol.

Soria SÁrz, C. (1987): Derecho de la información. Análisis de su concepto, San José de Costa Rica, ECAM.

Tenorio SÁnchez, P. J., et al. (dir.) (2014): La libertad de expresión, Su posición preferente en un entorno multicultural, Fundación Wolters Kluwer España, Madrid.

Terrou, F. (1970): La información. Barcelona, oikos-tau.

Tocqueville, A. (2005): Discursos y escritos políticos. CEPC.

Torres del Moral, A. y Navas, F. «Encuadramiento terminológico y evolución histórica de las libertades informativas», en Torres del Moral A. dir. (2009), Libertades informativas, COLEX, Madrid, pp. 15-70.

Truyol y Serra, A. (2015). Los derechos humanos, Madrid, Tecnos

Voyenne, B. (1970). Le Droit à l'information. Paris, Aubier-Montaigne. 
Title:

The complex configuration of a multifaceted freedom-right, the right to communicate. Historic references.

\title{
Summary:
}

I. Approach. II. Methodological difficulty of the historic references due to the diversity of its parameters. III. Several features or constant that not even the most advanced technologies are able to modify. IV. Historic view on the rights and freedoms. V. Declarations of rights at the end of the xviii century, the threshold of the new political order. VI. The belated recognition of the right to communicate. VII. The constitutionalization in the $7^{\text {os }}$ (20th c.). VIII. Recapitulation. The 21st century: The information society. IX. References.

\section{Resumen:}

Este estudio sobre la configuración del derecho a la información trata de poner de relieve las peculiaridades del mismo que explican que, por más que existan precedentes doctrinales bien lejanos, no haya podido constitucionalizarse en Europa hasta avanzado el siglo xx. Debiendo insistir en la necesidad de que no sea confundido con la libertad de expresión, muchas referencias que se hacen en perspectiva histórica tratan justamente de subrayar esa diferencia entre ambos derechos-libertades y por consiguiente se trata de negar que se pueda considerar información lo que solo es expresión. Si bien la mayor solera y maduración de la libertad de expresión tiende a absorver en si misma el derecho a la información como una facultad más de aquella, en el texto se justifica la diversa funcionalidad política de ambos y la diversa fundamentación filosófica de los regímenes que dan cobertura a una y otro.

\begin{abstract}
:
This work focuses on the origins of the right to communicate and aims to highlight some of the peculiarities that help explain that, even if there is a legal precedent that dates back centuries, its Constitutional adoption in Europe only happened well into the 20th century. We must insist that this right must not be confused with freedom of expression, as many references that deal with this topic from a historical perspective aim to highlight the differences between both rights/freedoms. Even if the stronger tradition and development of freedom of expression as a right tends to absorb the right to communicate as one of its parts, this text explains the different political func-
\end{abstract}


tion of both rights and points out the differences in the philosophical foundations of the legal framework that establishes one or the other.

\section{Palabras clave:}

Libertad de expresión, Historia del derecho a la información, Derecho y sociedad de la información.

\section{Keywords:}

Freedom of press, History of the Right to Communicate, Law and Information Society. 